\title{
Corporate Social Responsibility PT.Telkom Yogyakarta in the Framework of the Small and Medium Business Empowerment in DIY Province
}

\author{
Ayu Hasna Nabila ${ }^{1}$, Marita Ahdiyana ${ }^{2}$ \\ Department of Public Administration, Universitas Negeri Yogyakarta, Indonesia \\ 1'ayuhasna12@gmail.com, ${ }^{2}$ marita_ahdiyana@uny.ac.id
}

\begin{abstract}
The purposes of this research are to find out the Corporate Social Responsibility of PT Telkom Telkom in the context of empowering the small and medium business in DIY Province and to know the supporting and inhibiting factors. Corporate Social Responsibility has an important role in determining the performance of PT.Telkom's partnership program and realizing the economic development of small and medium entrepreneurs. This research is a descriptive study with a qualitative approach using primary data and secondary data. Data collection techniques are done through interviews, observation, and documentation. The technique for checking the validity of the data is triangulation of sources. While the data analysis technique uses the interactive model of Miles and Huberman which consists of the stages of data collection, data reduction and conclusion drawing. The results showed that the CSR of PT. Telkom Yogyakarta in the partnership program in empowering the small and medium business in Yogyakarta was not optimal in providing training and coaching, as well as lack of monitoring and control to all of its fostered partners. The supporting factors of PT.Telkom Yogyakarta's CSR are the accuracy of the fostered partners in returning loan funds, and the CSR funds. While the inhibiting factor is the fostered partners who does not repay the loan of funds, both due to intentional or inadvertent elements.
\end{abstract}

Keywords: Corporate Social Responsibility, Small and Medium Business, Empowerment.

\section{Introduction}

The partnership program is a company activity to collaborate with the aim of helping each other achieve mutual goals and benefits. This is in accordance with Law no. 19 of 2003 and Law no. 20 of 2008 which states that the partnership program is business cooperation between small and medium entrepreneurs based on the principles of mutual need, trust, strengthening and benefits. As stated by Notoatmodjo (2003), a partnership is a formal collaboration between individuals, groups or organizations to achieve a specific task or goal. One of the goals of the partnership program is to increase the ability of small businesses to become resilient and independent by utilizing funds from the BUMN's profit share.

Based on the Regulation of the Minister of State for SOEs Number Per-02 / MBU / 7/2017 on July 5, 2017, State Owned Enterprises (BUMN) are also required to carry out the Partnership Program. The partnership program is a form of Corporate Social Responsibility, which aims to build the image of a company because it greatly affects public trust in the company. The broad 
goal of Corporate Social Responsibility is to create a higher standard of living, while maintaining corporate profitability, for the community both inside and outside the company (Hopkins, 2003: 28).

PT. Telkom Yogyakarta Indonesia is one of the BUMNs that carries out a partnership program through the provision of financial assistance to small and medium entrepreneurs as a form of CSR managed by the Community Development Center unit. The target of implementing the partnership program of PT. Telkom Yogyakarta is in the fields of industry, agriculture, livestock, fisheries, trade and services in several DIY areas, namely Bantul, Sleman, Gunungkidul, Kulonprogo, and Yogyakarta City. According to PT. Telkom.

Yogyakarta Indonesia, this program has several objectives, namely increasing the income of small businesses and the community, increasing the role and empowerment of the community, increasing added value for partners, as well as increasing rural, regional and national economic growth, synergizing business forms and to complement each other. regarding the needs of one another, so it is hoped that the economic wheels of the community can run smoothly, especially in the Telkom DIY Business Area, where the purpose of all of this is for the benefit of the wider community.

In running the partnership program, PT. Telkom Yogyakarta also pays attention to the community, especially around the company as a commitment of Good Corporate Social Responsibility. However, there are still problems at PT. Telkom Yogyakarta, such as the inaccurate target of distributing revolving funds which can cause bad credit at the loan repayment stage, there are still fostered partners who are classified as less active, lack of intensive and routine guidance to all its fostered partners, as well as PT. Telkom Yogyakarta is still not very proactive in socializing to the wider community, especially in remote areas.

Basically, the partnership program is also recommended to provide guidance that includes technology training, accommodating production / presenting results, and providing understanding and skills to MSMEs. But in reality, PT. Telkom Yogyakarta only provides financial assistance, while the guidance has not been implemented optimally. So that in the condition of the fostered partners there are partners who have been able to develop their business, and have even opened jobs for other communities. But on the other hand, there are also fostered partners whose businesses have not experienced better development, and are even classified as inactive partners.

Based on the description above, the researchers are interested in examining the corporate social responsibility of PT. Telkom Yogyakarta in order to empower MSMEs in DIY. This research was conducted to determine the corporate social responsibility of PT. Telkom Yogyakarta in the framework of empowering MSMEs in DIY as well as supporting factors and inhibiting factors for corporate social responsibility of PT. Telkom Yogyakarta in order to empower MSMEs in DIY

ISO 26000 in Daniri (2008: 13) translates Corporate Social Responsibility as the social responsibility of an organization for the impact of its decisions and activities on society and the environment, through transparent and ethical behavior. Then according to Prastowo and Huda (2011: 17) CSR is a natural mechanism for a company to 'clean up' the big profits it gets. As is well known, the company's methods of obtaining profits sometimes harm others, be it unintentional or deliberate. It is said to be a natural mechanism because CSR is a consequence of the impact of decisions or activities made by the company, so the company's obligation is to reverse the condition of the people who experience this impact to a better condition.

Rahman (2009) explains that there are 3 indicators to measure corporate social responsibility. 
These indicators are continuity and sustainability, community empowerment, and two ways. Next will be explained as follows:

a) Continuity and sustainability, which means that it is a vital element of CSR. CSR is something that is characterized by a long term perspective, not instant, happening, or booming. CSR is a mechanism for activities that are planned, systematic, and can be evaluated.

b) Community empowerment, which means that CSR is to give encouragement to the community by empowering people to be able to become more independent from their respective economic wheels.

c) Two ways, which means that CSR programs are two-way. Companies no longer only act as communicators, but must also be able to listen to the aspirations of their communities. This can be done by means of a need assessment, namely a survey to determine the needs, desires, interests and wants of the community.

From these various theories, researchers used Reza Rahman's theory to determine the corporate social responsibility of PT. Telkom Yogyakarta in empowering MSMEs in DIY that has been implemented. Corporate social responsibility has an important role in determining the performance of the partnership program of PT. Telkom Yogyakarta and realizing the economic development of small and medium entrepreneurs.

\section{Research Methods}

\subsection{Types of Research}

This type of research is a descriptive study with a qualitative approach. This method is used to describe the results of research and to describe phenomena that occur in society. With this method is expected to be able to assist researchers in analyzing and describing phenomena in society related to the corporate social responsibility of PT. Telkom Yogyakarta in Empowering UMKM in DIY.

\subsection{Time and Place of Research}

Research activities regarding the CSR partnership program are carried out at PT. Telekomunikasi Indonesia Witel Yogyakarta, located at Jalan Yos Sudarso No.9, Kotabaru, Kec. Gondokusuman, Yogyakarta City, Yogyakarta Special Region. While the time of this research was carried out for 3 months, starting from 15 November 2019 - 13 April 2020.

\subsection{Research Subject}

Research subjects are research informants who are able to provide information in the implementation of this research, so that the data obtained is accurate and reliable. The choice of subjects in this study was chosen based on the data needs required by the researcher, namely people who can provide information related to how the Corporate social responsibility of PT. Telkom Yogyakarta in order to empower MSMEs in DIY. The following are the research subjects in this study: 
a) Mr. Bambang Rahmadi as HR and CDC (Community Development Center) Manager,

b) Mrs. Sri Wahyuni as Assistant Manager of CDC PT. Telkom Yogyakarta,

c) Mr. Agus Irianto as a partner in the trade sector in the partnership program of PT. Telkom Yogyakarta,

d) Mr. Yusuf Saputra as a partner in the trade sector in the partnership program of PT. Telkom Yogyakarta.

\subsection{Data and Data Sources}

Sugiyono (2017) explains that data sources can use primary data sources in the form of interviews and observations, while secondary data sources are book documents, journals, news publications, photos, notes, regulations and others. Primary data obtained through this research include data obtained through interviews with resource persons regarding the partnership program of PT. Telkom Yogyakarta, as well as observation data covering various aspects that can be observed in the business of the fostered partners such as the existence of the fostered partners 'business, the economic conditions of the fostered partners, the development of the fostered partners' business, the communication system between PT Telkom Yogyakarta and the fostered partners, and the infrastructure for program activities. partnership of PT. Telkom Yogyakarta. Meanwhile, secondary data used in this study were printed documents related to the partnership program obtained from PT. Telkom Yogyakarta, books, website of PT. Telkom Yogyakarta, and laws related to partnership programs, photos of partnership program activities, and reports of partnership program activities for 2017-2019.

\subsection{Research Instruments}

According to Sugiyono (2015: 222) in qualitative research, the research instrument is the researcher himself. Therefore, in this study, the researcher as the main instrument by developing interview and observation guidelines with the help of data collection equipment such as cameras, voice recorders, interview guides, field notes, and guidelines related to the field under study.

\subsection{Data Collection Technique}

a) Observation

Sugiyono (2015: 204) explains that observation is an activity of loading research on an object In this study, researchers used participant observation.

b) Interview

Sugiyono (2017) explains that data collection techniques can be done in a structured or unstructured manner and can be done through face-to-face or telephone. In this study using semi-structured interviews to extract primary data from research informants.

c) Documentation

Sugiyono (2015: 329) explains that documentation is a method used to obtain data and information in the form of books, archives, documents, written numbers and images in the form of reports and information that can support research. The documentation used in this research includes photos of activities, activity voice notes, activity files and releases of PT. 
Telkom Yogyakarta. The documentation data obtained from this study include photos of the partnership program activities of PT. Telkom Yogyakarta, report on partnership program activities of PT. Telkom Yogyakarta 2017-2019, foster partner profile report book 2017-2019, data portal and official web (Source: www.telkom.co.id accessed on 22 April 2020 at 20.00 WIB).

\subsection{Data Analysis Technique}

The technique of checking the validity of the data used in this study was to use technical triangulation. Researchers triangulated techniques using different data collections to obtain data from the same data source. The data collection techniques are in the form of interviews, observation, and documentation. In this study, the researcher will compare a document related to the interview results, besides that the researcher will also compare the observed data and the interview data.

The data analysis technique used in this study is the interactive model of Miles and Huberman (2014) which consists of three activity lines, namely data reduction, data presentation, conclusion drawing or verification. In the flow of data reduction, the researcher will summarize, select the main things, focus on the important things, and look for themes and patterns. In the flow of data presentation is carried out in the form of a short description according to what is being studied so that it is easier to interpret the data regarding the CSR partnership program of PT. Telkom Yogyakarta. in the flow of conclusions or verification, the researcher tries to understand the meaning and essence of the problem. In this study, draw conclusions done after the researcher describes the data and conducts discussions related to the problems taken by the researcher.

\section{Research Results and Discussion}

The government's decision regarding the existence of CSR is of course based on a thorough study and consideration. One thing that must be considered is the extent to which this program can play a role in advancing the country's economy, especially for small and medium entrepreneurs. In general, the community is greatly helped by the partnership program. This is because the Indonesian people, especially small and medium entrepreneurs, really need a lot of capital to build and continue a business with a weak economy. Therefore, PT.

Telkom Yogyakarta also provides assistance in lending funds and guidance to its fostered partners through a partnership program, with low interest.

PT. Telkom Yogyakarta is a state-owned company that is well known in the eyes of the community. The success of the program cannot be separated from the actors implementing the program. As the organizer of corporate social responsibility in DIY, PT. Telkom Yogyakarta hopes for the support of the community, especially small entrepreneurs who will become partners. The involvement of the actors is shown by the performance and support of the activity organizers and their fostered partners in the implementation of the corporate social responsibility of PT. Telkom Yogyakarta in order to empower MSMEs in DIY. 


\section{1 Corporate Social Responsibility PT. Telkom Yogyakarta in Empowering UMKM in DIY}

\section{a) Continuity and Sustainability Indicators}

Continuity and sustainability are generally defined as the company's efforts to continue implementing programs / activities to have a long-term impact, characterized by a long term perspective, not instant, happening, or booming. CSR is a mechanism for activities that are planned, systematic, and can be evaluated.

Reza Rahman (2009) states that this indicator must be done by measuring the provider's power against the expectations, desires, aspirations and demands of customers.

PT. Telkom Yogyakarta in its partnership program tries to provide the wishes, aspirations and demands of customers through loan funds with significant increases every year and adjusts how much the needs of each region / sector are so that the provision of assistance can run optimally so that it is expected to be successful in helping the government to realize continuity and sustainability. The following is data on the distribution of funds based on the annual report book of the partnership program of PT. Telkom Yogyakarta.

Table 1. Report on loan funds to fostered partners for the years 2002 to the third quarter of 2019 (data per

\begin{tabular}{ccc} 
& district / city) & \\
\hline District/City & $\begin{array}{c}\text { Fostered } \\
\text { Partners }\end{array}$ & $\begin{array}{c}\text { Amount of } \\
\text { funds (Rp) }\end{array}$ \\
\hline Bantul & 961 & 28.186 .700 .000 \\
Gunungkidul & 174 & 4.755 .500 .000 \\
Yogyakarta & 641 & 19.654 .200 .000 \\
Kulonprogo & 158 & 3.398 .500 .000 \\
Sleman & 1.281 & 31.916 .600 .000 \\
Total & 3.215 & 87.911 .500 .000 \\
\hline Source: PT. Telkom Yogyakarta Yogyakarta, 2019.
\end{tabular}

Table 2. Report of partnership funds to fostered partners for the year 2002 to the third quarter of 2019 (per

\begin{tabular}{ccc}
\multicolumn{3}{c}{ business sector) } \\
\hline $\begin{array}{c}\text { Business } \\
\text { Sectors }\end{array}$ & $\begin{array}{c}\text { Fostered } \\
\text { Partners }\end{array}$ & $\begin{array}{c}\text { Amount of funds } \\
\text { (Rp) }\end{array}$ \\
\hline Industry & 786 & 23.851 .000 .000 \\
Services & 622 & 20.732 .100 .000 \\
Others & 32 & 1.168 .500 .000 \\
Trade & 908 & 25.623 .200 .000 \\
Fishery & 55 & 1.483 .800 .000 \\
Plantation & 87 & 879.100 .000 \\
agriculture & 440 & 7.444 .700 .000 \\
The farm & 285 & 6.729 .100 .000 \\
Total & 3.215 & 87.011 .500 .000 \\
\hline
\end{tabular}

From some of the tables above, it can be seen that the distribution of funds to DIY MSMEs 
from year to year has not been too stable because in 2018 there was an increase in lending, but in 2019 there was a decrease in lending. It can also be seen that the industrial sector and the trade sector rank at the top of the types of MSMEs that receive loan funds from PT. Telkom Yogyakarta, this is because the industrial and trade sectors have big prospects in recent years.

The sustainability and sustainability of this partnership program is demonstrated by providing assistance to small and medium entrepreneurs by lending funds held annually from 2002 to the present for their foster partners at relatively low interest rates compared to banking. PT. Telkom Yogyakarta has also provided tolerance for time if there are fostered partners who experience problems such as unexpected disasters, which causes them difficulty in repaying their loan funds.

\section{b) Community Empowerment Indicators}

Community empowerment is important in measuring social responsibility in a company. Basically, community empowerment is an activity to encourage people to create an innovation or product so that people become more independent of their respective economic wheels respectively. In the partnership program of PT. Telkom Yogyakarta has various forms of empowering its community (fostered partners), namely workshop, debriefing, bazaar, e-learning training, and exhibition. Therefore, if the community empowerment provided by PT. Telkom Yogyakarta Yogyakarta is good, meaning that its social responsibility can also be considered good. Thus, community satisfaction with the company can be used as a good indicator of corporate social responsibility.

Rahman (2009) defines that this indicator is a benchmark where CSR programs need to carry out a series of activities to empower their communities. The measurement of the partnership program in the indicators of community empowerment in this partnership program starts from how far the provisioning, training, workshop, exhibition and bazaar activities carried out can reach and make changes to small and medium entrepreneurs, and to what extent the partnership program has Yogyakarta can be said to be not good. This can be seen from the empowerment of communities in this program that shows developments in terms of economy, production, and increasing employment opportunities. However, in its implementation there are still a number of problems in the implementation of its activities, such as the absence of a regular schedule to visit the fostered partners to see how their business is progressing, or to find out the difficulties they are facing then help find solutions or solutions and during coaching they are often only given things that are theoretical in nature and during the exhibition, only MSMEs that have the best specifications or more value can be included in the exhibition.

\section{c) Two Ways Indicator}

Two-way communication is a form of agreement on how the wants and needs of the two parties can be fulfilled through deliberations / meetings based on applicable regulations. In the CSR program, two-way communication must be carried out (Two Ways). Companies are no

longer merely acting as communicators, but must also be able to listen to the aspirations of their communities, this can be done with a need assessment, which is a survey for know the needs, desires, interests and wants of the community. This requires solid coordination in order to create a consensus on what is needed by PT. Telkom Yogyakarta to the prospective partners and what is 
needed by the prospective partners to PT. Telkom Yogyakarta.

Rahman (2009) explains that two-way communication is the most important measure in collaborating between the two parties. If there is miscommunication or disagreement from one of the parties, it will cause the relationship between the two to be disturbed or stretched. Two-way communication on the partnership program of PT. Telkom Yogyakarta is shown by providing activities for the fostered partners to fulfill the needs of the two parties, namely deliberations and surveys. Through deliberations / meetings, the company creates an information forum to disseminate information about the partnership program for local communities that can be understood and accepted by the community. PT. Telkom Yogyakarta can submit requirements for fostered partners. On the other hand, the fostered partners can also raise their aspirations so that the needs of both parties can be met. Then survey activities. PT. Telkom Yogyakarta conducted a survey first to see the feasibility and condition of the existing business of the prospective fostered partners.

Two-way communication to the fostered partners provided by PT. Telkom Yogyakarta Yogyakarta can be said to be not good. This can be seen when entering into an agreement between the two parties to meet the applicable requirements, in which PT. Telkom Yogyakarta Yogyakarta immediately explained these requirements which could be said to be complicated regardless of whether the fostered partners had objections or not. Second, the lack of human resources on the part of PT. Telkom Yogyakarta when conducting a survey to fostered partners so that the resulting data is less accurate and specific.

\subsection{Supporting and Inhibiting Factors for Corporate Social Responsibility PT. Telkom Yogyakarta in the Context of Empowering MSMEs in DIY}

In implementing the partnership program, the role of the community, PT. Telkom Yogyakarta, and its fostered partners are important components that influence the success of the program. The following are some of the supporting factors for the CSR program, namely:

a) There are facilities (funds) from PT. Telkom Yogyakarta in supporting every activity of the partnership program to develop small and medium enterprises in the DIY community.

b) People who trust the products of PT. Telkom Yogyakarta, so that PT. Telkom Yogyakarta makes a profit which is then accumulated for corporate social responsibility programs.

c) Fostered partners of PT. Telkom Yogyakarta, which pays loan repayments on time, so that the turnover of loan funds can run smoothly.

There are several inhibiting factors that occur in the partnership program, namely:

a) Lack of human resources on the part of PT Telkom Yogyakarta in carrying out various partnership program activities. Another inhibiting factor is the occurrence of an economic crisis and falling prices that hit one sector. For example, when there was an outbreak of bird flu which caused livestock business to fall. This resulted in reduced demand for poultry which resulted in delays in loan repayments.

b) The occurrence of natural disasters, for example when the disaster of Mount Merapi erupted. From this incident, many fostered partners could not pay their loans on time, so PT. Telkom Yogyakarta provides another alternative way of increasing the grace period for repaying the loan. If within the grace period the fostered partner is still unable to pay it off, then PT. Telkom Yogyakarta will stop the existing interest so as not to make it difficult for customers due to 
increasing loans.

c) The existence of a large company that wants to be a partner of PT. Telkom Yogyakarta. This clearly violates the provisions because the aim of this program is to develop small and medium enterprises. If a large businessman becomes a partner of PT. Telkom Yogyakarta, so the existing funds cannot be used to help small entrepreneurs. Seeing this, PT. Telkom Yogyakarta was forced to refuse and provide an explanation that entrepreneurs who are already advanced are more expected to help small entrepreneurs by providing jobs, instead of taking land loans from small entrepreneurs.

d) The number of small entrepreneurs in the untouched areas. This is because the community does not have enough information about the PT. Telkom Yogyakarta. they do not know that PT. Telkom Yogyakarta has a loan program with very low interest and easy terms. The community only knows that borrowing funds is only done by banks with high interest rates, which still does not dampen the desire of small entrepreneurs to borrow funds. Seeing this, PT. Telkom Yogyakarta tries to provide information through outreach and outreach to communities in remote areas through cooperatives.

e) Then there are fostered partners who do not make loan repayments due to deliberate factors and bad intentions, then PT. Telkom Yogyakarta will black list these entrepreneurs.

\section{Conclusion}

Based on the results of research and discussion of research entitled "CSR PT. Telkom Yogyakarta in the Context of Empowering DIY MSMEs ", it can be concluded that CSR in the partnership program in empowering DIY MSMEs is not optimal in providing training and coaching, as well as a lack of monitoring and control to all its fostered partners.

This can be seen from the indicators of the company's CSR theory according to Reza Rahman (2009) as follows:

a) Continuity and sustainability (sustainable and sustainable).

Based on Yogyakarta indicators, the implementation of the CSR program of PT. Telkom Yogyakarta is quite good. This can be seen from the systematic design of activities and the amount of funds distributed in each region that has been adjusted to the needs, but there are still problems such as bad credit and guidance that has not been fully carried out regularly. So that the sustainability of the program is hampered when there are fostered partners who are late or do not repay the loan at all.

b) Community empowerment (community empowerment).

Implementation of CSR activities of PT. Telkom Yogyakarta based on this indicator is still not good enough. because even though PT. Telkom Yogyakarta has carried out various coaching and training such as debriefing, workshop, exhibition, bazaar. However, there are things that deviate from the basis of the system, causing the initial goal not to match expectations. Then at the exhibition, not all fostered partners are given the opportunity to participate in these activities. However, only a few fostered partners were selected to be included.

c) Two Ways (two-way communication) Implementation of CSR activities of PT. Telkom 
Yogyakarta based on this indicator is still not good enough. This can be seen in the counseling of PT. Telkom Yogyakarta regarding a partnership program for the community only through village cooperatives. However, from its implementation, PT. Telkom Yogyakarta is less proactive in delivering and disseminating partnership programs to remote or underdeveloped communities. So that most fostered partners only know about the program through their customers from their business. Then when making an agreement between the two parties to meet the applicable requirements, where PT. Telkom Yogyakarta immediately explained these requirements which could be said to be complicated regardless of whether the fostered partners had objections or not.

As for suggestions that can be given to PT. Telkom Yogyakarta as a state company in implementing CSR, namely:

a) Increase socialization about the partnership program of PT. Telkom Yogyakarta to the community, so that many people are aware of the program.

b) Provide regular assistance, so that CDC PT. Telkom Yogyakarta really knows the conditions in the field of its fostered partners directly, not only through the quarterly reports from the fostered partners.

c) Involving fostered partners who are classified as less smooth in their business in exhibition activities, so that these partners have enthusiasm and ideas to return to developing their business.

d) Informing the existence of this partnership program on a regular basis and with a wider scope, so that small and medium entrepreneurs can find out about the Partnership Program of PT. Telkom Yogyakarta.

e) Conduct intensive training and coaching for SMEs according to their business needs and their educational background.

f) Adding staff for conducting surveys related to fostered partners and a clear division of labor, so that it is hoped that the entire series of partnership programs can be carried out well and can achieve the initial objectives of holding the partnership program of PT. Telkom Yogyakarta.

g) Emphasize the use of digital so that all activity processes can be carried out more easily and well monitored.

\section{References}

[1] Adi, Isbandi Rukminto. (2005). Ilmu Kesejahteraan Sosial dan Pekerjaan Sosial. FISIP UI PRESS.

[2] Adisasmita, Rahardjo. (2005). Dasar-dasar Ekonomi Wilayah. Penerbit Graha

[3] Ardianto, Elvinaro dan Dindin Machfudz. (2011). Efek Kedermawanan Pebisnis dan CSR. Jakarta: Elex Media Komputindo.

[4] Daniri. (2008). Standardisasi Tanggung Jawab Sosial Perusahaan. Jakarta: Gramedia Pustaka Utama.

[5] Hafsah, Mohammad Jafar. (2000). Kemitraan Usaha: Konsepsi dan Strategi. Jakarta: PT. Pustaka Sinar Harapan.

[6] Kartini, Dwi. (2009). Corporate Social Responsibility: Transformasi Konsep Sustainability Management dan Implementasi di Indonesia. Bandung: Refika Aditama.. 
[7] Rahman, Reza. (2009). Corporate Social Responsibility Antara Teori dan Kenyataan. Jakarta : Buku Kita

[8] Sugiyono. (2017). Metode Penelitian Kuantitatif, Kualitatif, dan R\&D. Bandung: Alfabeta.

[9] Singarimbun, Masri dan Sofian Effendi. (1989). Metode Penelitian Survey. LP3ES. Jakarta.

[10] Saidi, Abidin. (2014). Corporate Social Responsibility Alternatif Bagi Pembangunan Indonesia, Jakarta: ISCD.

[11] Solihin, Ismail. (2011). Corporate Social Responsibility : From Charity to sustainability, Jakarta: Salemba Empat.

[12] Suyanto, Bagong. (2005). Metode PenelitianSosial. Jakarta: Kencana Prenada Media Group.

[13] Susanto, A.B. (2009). Reputation Driven Corporate Social Responsibility Pendekatan Startegic Management Dalam CSR. Jakarta: Erlangga

[14] Wibisono, Yusuf. (2007). Membedah Konsep dan Aplikasi CSR. Gresik: Fascho. (2017). Corporate Social Responsibility PT. Telkom Yogyakarta Indonesia.

[15] www.telkom.co.id Accessed on 22 April 2020 at 20.00 WIB 